\title{
Perancangan Alat Pengunci Pintu dan Sistem Informasi Menggunakan RFID Berbasis Ardiuno
}

\author{
Al Thariqh Muhammad Quithary ${ }^{1}$ Hastuti $^{2}$ \\ 1.2Universitas Negeri Padang \\ Jl.Prof.Dr.HamkaAirTawarPadang \\ quithary8@gmail.com ${ }^{1}$, Hastuti@ft.unp.ac.id ${ }^{2}$
}

\begin{abstract}
The use of door locks as well as safety, has been used but its function has not been optimal. The development of information systems and increasingly modern technology shows that the use of RFID as an electric lock can optimize users to access the room by simply tagging the ID card on the part that has been provided when the door is open and closed. The purpose of designing a door locking device and indoor information system can provide information on the whereabouts of lecturers / users in the room through a status that can be seen and accessed on the telegram application, using the Arduinobased RFID approach. The design method used uses the Telegram application as a media for information on the user's presence in making it easier for someone who wants to connect with the user to find out their whereabouts through the RFID card as a lock which is simultaneously connected to the circuit as a user of information from the user / lecturer who monitors it. The results of this design use the RFID component as an electric key connected to the Arduino Mega 2560, the Driver Relay as a connecting switch on or off from the Selonoid Door Lock on the door, the use of the RTC as an indicator of lecturer status change time and an automatic switch to activate and design tools and use the ESP8266 as a liaison between the design of the tool and the Telegram information media using the internet network (Wifi). This design produces a door locking system that can inform the whereabouts of lecturers in the room through a led indicator on the front door and also a telegram application that can be checked remotely for the given status, namely Yes, Busy, and None.
\end{abstract}

Keywords - Sistem Informasi, RFID, Arduino Mega 2560, Selonoid Door Lock, Telegram

Abstrak - Penggunaan kunci pintu yang sekaligus sebagai pengaman, sudah digunakan namun belum optimal fungsinya. Berkembanganya system informasi dan teknologi yang semakin canggih menunjukkan bahwa penggunaan RFID sebagai pengunci elektrik dapat mengoptimalkan para pengguna untuk mengakses ruangan hanya dengan men-tag kartu ID pada bagian yang sudah disediakan pada kondisi pintu terbuka dan tertutup. Tujuan perancangan alat pengunci pintu dan system informasi dalam ruangan dapat memberikan informasi keberadaan dosen/pengguna dalam ruangan melalui status yang dapat dilihat dan diakses pada aplikasi telegram, dengan menggunakan pendekatan RFID berbasis arduino. Metode perancangan yang digunakan yaitu menggunakan Aplikasi telegram sebagai media informasi keberadaan pengguna dalam ruangan mempermudah seseorang yang ingin berhubungan dengan pengguna untuk mengetahui keberadaannya melalui kartu RFID sebagai pengunci yang sekaligus terhubungn dengan rangkaian sebagai pemberi informasi dari pengguna/dosen yang bersangkutan. Hasil perancangan ini menggunakan komponen RFID sebagai Kunci Elektrik yang terhubung dengan Arduino Mega 2560, Driver Relay sebagai penghubung saklar on atau off dari Selonoid Door Lock pada pintu, penggunaan RTC sebagai indikator waktu pergantian status dosen dan saklar otomatis untuk mengaktifkan dan menonaktifkan rancangan alat dan penggunaan ESP8266 sebagai penghubung antara rancangan alat dengan media informasi Telegram dengan menggunakan jaringan internet (Wifi). Perancangan ini menghasilkan system pengunci pintu yang sekaligus dapat menginformasikan keberadaan dosen dalam ruangan melalui indicator led yang terdapat pada depan pintu dan juga aplikasi telegram yang dapat di periksa dari jarak jauh untuk status yang dberikan yaitu Ada, Sibuk, dan Tidak Ada.

Kata kunci - Sistem Informasi , RFID, Arduino Mega 2560, Selonoid Door Lock, Telegram

\section{Pendahuluan}

Perkembangan Ilmu Pengetahuan dan Teknologi khususnya pada bidang elektronika mengalami kemajuan yang cukup pesat dan memberikan dampak besar bagi masyarakat untuk memenuhi kebutuhan sehari-hari. Kemajuan dari perkembangan tersebut membuat manusia dapat memanfaatkan bentuk teknologi yang diciptakan untuk mempermudah aktivitas kehidupan, misalnya seperti pintu pada sebuah bangunan gedung [1].

Berdasarkan fungsinya, pintu sangat dibutuhkan sebagai akses keluar masuk manusia atau pembatas antara satu ruangan dengan ruangan lainnya. Sehingga penggunaan pintu tersebut membutuhkan sistem keamanan yang baik untuk menghindari upaya pengamanan dari pencurian[2]. Penggunaaan sistem pengaman pintu dapat dilakukan untuk mencegah tindakan yang tidak diinginkan atau kriminalitas. Sistem pengunci pintu saat ini masih menggunakan kunci konvensional, sehingga kurang efektif dan efisien untuk rumah yang memiliki banyak ruangan dengan banyaknya kunci yang akan dibawa kemana-mana[3]. Selain itu, kunci konvensional mudah untuk ditiru dan dibuka oleh pencuri. Sehingga diperlukan pengunci atau sistem kunci yang dapat memberikan keamanan dalam ruangan dengan karaketristik tidak mudah ditiru dan multi fungsi dengan 
arti dapat digunakan untuk semua ruangan tanpa membawa banyak kunci [4].

Sistem keamanan yang dipasang pada setiap pintu mempunyai perbedaan, tergantung dari funggsi ruangan. Ruangan yang membutuhkan keamanan cukup ketat dapat membatasi akses masuk seperti pada ruangan server, laboratorium, atau ruangan dosen yang tidak dapat dimasuki oleh sembarangan orang [5]. Salah satu cara membuat sistem pengaman pintu yaitu dengan cara mengganti jenis kunci pintu yang digunakan dari kunci manual (kunci mekanik) menjadi kunci elektronik seperti dengan menggunakan sandi atau kode, remote control, sidik jari, smart card atau dengan deteksi wajah [6].

Beberapa penelitian telah dibuat terkait dengan system pengaman kunci ini, seperti pengaman kunci dengan menggunakan RFID sebagai kunci elektronik yang dapat mengakses pintu terbuka dengan mendaftarkan ID yang digunakan[7]. Salah satu penelitian dari mahasiswa politeknik negeri sriwijaya membuat rancanagan sistem akses membuka pintu dengan menggunakan teknologi identifikasi sidik jari e-KTP sebagaia pengaman pintu elektronik pada ruangan dosen [8].

Penelitian pengaman pintu dan sistem informasi keberadaan dosen ini menggunakan RFID sebagai pengunci sekaligus pengaman pintu dengan mendaftarkan ID dari pengguna dalam rungan dosen[9]. Untuk yang ingin mengakses ruangan dosen ini tanpa memilki ID atau izin dari yang bersangkutan maka pintu tidak akan terbuka atau tidak dapat diakses. Penggunaan RFID ini dilakukan sebagai pengaman pintu dari pengguna yang tidak berhak masuk dalam ruangang yang tidak mempunyai ID tersebut [10].

Pada penelitian siti, Rosyana[9], sistem pengamanan pintu pada ruangan dosen dengan menggunakan RFID sebagai kunci elektronik yang hanya dimiliki oleh dosen dalam ruangan tersebut. Perbedaan dengan rancangan yang diteliti saat ini yaitu rancangan ini dapat langsung memberikan informasi keberadaan dosen atau pengguna dalam ruangan dari jarak jauh menggunakan aplikasi yaitu Telegram. Penggunaan telegram sebagai media informasi keberadaan dosen dalam ruangan secara otomatis yang sudah dapat dikatakan modern. Penggunaan telegram dilakukan dengan menghubungkan rangkaian ESP8266 pada arduino mega sebagai pengendali terpusat dengan bantuan sinyal atau jaringan internet yang diberikan agar rancangan dari alat dapat memberikan informasi melalui telegram.

\section{METODE}

Metode perancangan ini menggunakan hardware dan software. Untuk perancangan hardware menggunakan Arduino Mega 2560 sebagai pengendali terpusat, RFID sebagai kunci elektronik, Selonoid Door Lock sebagai pengunci pintu dari dalam ruangan yang dapat membuka atau menutup pintu sesuai dengan informasi yang dikirimkan, Driver Relay sebagai pengendali On/Off selonoid Door Lock untuk membuka atau menutup pintu. Penggunaan ESP8266 sebagai modul wifi yang berfungsi sebagai penghubung antara rancangan alat dengan aplikasi telegram dengan menghubungkan ke jaringan wifi. Selanjutnya penggunaan RTC sebagai pembatasan waktu otomatis untuk akses pintu dan status keberadaan dosen pada rancangan. Dimana rancangan alat akan hidup dan mati sesuai dengan waktu yang diberikan melalui program.

\section{A. Blok diagram}

Diagram blok sistem merupakan salah satu bagian terpenting dalam perancangan dan pembuatan alat, karena dari diagram blok dapat mengetahui prinsip kerja dari keseluruhan rangkaian. Tujuan rancangan ini yaitu memudahkan proses perancangan dan pembuatan pada masing-masing bagian, sehingga akan membentuk suatu sistem yang sesuai dengan perancangan yang diharapkan, secara garis besar prinsip kerja dari sistem yang dibuat ini seperti terlihat pada gambar 1 .

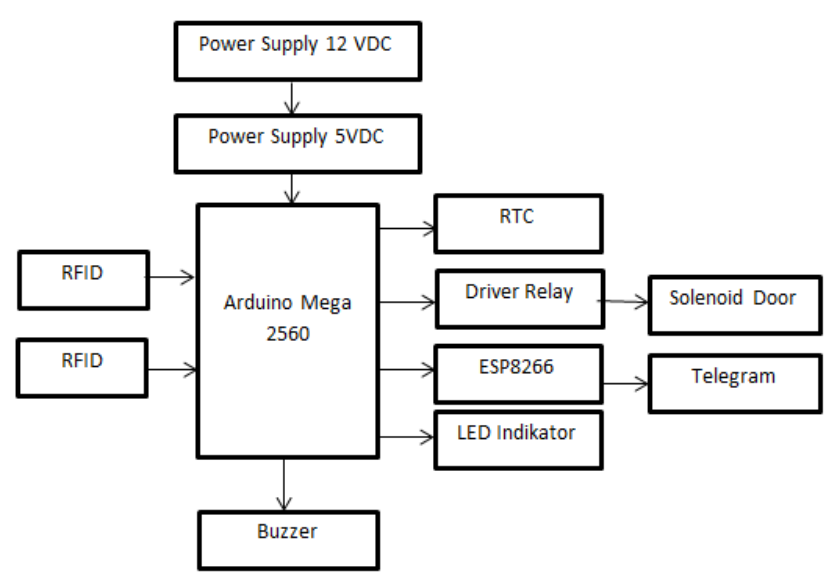

Gambar 1. Blok diagram

Penjelasan gambar 3 pada blok diagram diatas:

1. RFID (Radio Frequency Identification) sebagai media penyimpanan ID atau data. Cara kerjanya adalah dengan mencocokkan data atau ID yang tersimpan dalam memori tag dengan data yang dikirim oleh Reader. RFID Reader yang digunakan RC522 merupakan alat yang digunakan untuk membaca data atau ID yang terdapat pada kartu saat didedaktkan atau di tag pda RFID Reader untuk akses buka/tutup pintu. Perancangan ini terdapat dua buah RFID yang dipasang pada bagian pintu bagian luar dan dalam ruangan.

2. Arduino Mega 2560 berfungsi sebagai pusat pengendali sesuai dengan input yang dimasukan. Semua input atau output akan tersimpan dan 
diproses oleh memori arduino sesuai dengan program yang digunakan.

3. RTC (Real Time Clock) merupakan suatu chip(IC) yang memiliki fungsi sebagai penyimoan waktu dan tanggal pada rancangan alat yang akan dikontrol aktif atau tidak dengan waktu yang dibuat.

4. Driver Relay merupakan penghubung antara selonoid door lock dengan arduino yang berfungsi sebagai daya yang diperlukan untuk membuka atau menutup pintu degan mengaktifkan driver relay terlebih dahulu.

5. Solenoid Door Lock berfungsi sebagai pembuka atau penutup pintu ruangan secara elektronik dan otomatis pada pintu.

6. ESP8266 merupakan modul wifi yang berfungsi sebagai penghubung rancangan alat dengan jaringan internet untuk mengetahui keberadaan dosen melalui aplikasi Telegram.

\section{B. Perancangan Hardware}

\section{Perancangan Mekanik}

Perancangan ini bertujuan mempermudah serta mengurangi tingkat kesalahan dalam membuat Hardware sehingga menghasilkan hasil yang optimal. Pembuatan rancangan mekanik dilakukan dengan menggunakan software SketchUp. Pembuatan mekanik alat ini menggunakan bahan akrilik dengan ketebalan 2 mm digunakan sebagai kerangka dari komponen yang digunakan. Pada perancangan tedapat dua buah box dalam bentuk persegi dan persegi panjang dengan ukuran yang berbeda. Box 1 digunakan sebagai box kumpulan semua kompenen yang terdapat pada bagian luar pintu sebagai akses buka dan tutup pintu dari luar ruangan. Selanjutnya box 2 berguna sebaga tempat tag kartu ID dari dalam ruangan untui membuka dan menutup pintu dari dalam ruangan sekaligus untuk pergantiaan status pada dosen dalam. Berikut adalah rancangan Mekanik pada gambar 2 .

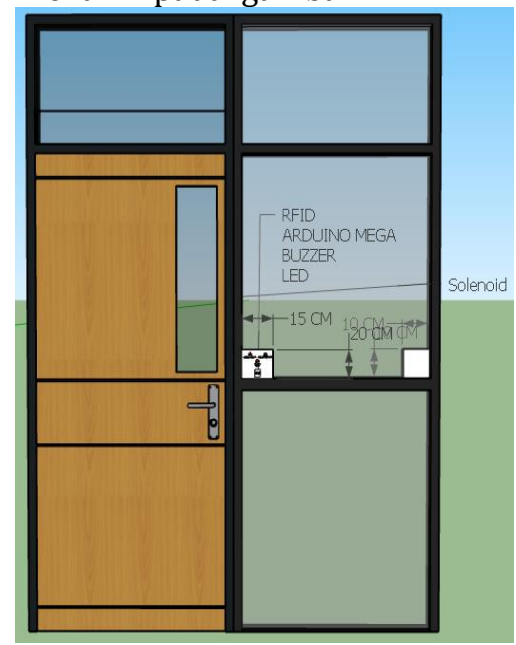

Gambar 2. Perancangan Mekanik

\section{Perancangan Rangkaian Elektronika}

Pada rangkaian elektronika, terdapat komponen yang digunakan yaitu, power suplay sebagai penurun tegangan untuk menjadi tegangan masukan dari step down converter, lalu tegangan dari step down converter diturunkan lagi untuk menjadi tegangan masukan mikrokontroler yang sebagai pusat kontrol sistem dihubungkan ke RFID, Driver Relay, Selonoid Door Lock,RTC, ESP8266 dan LED Indikator .

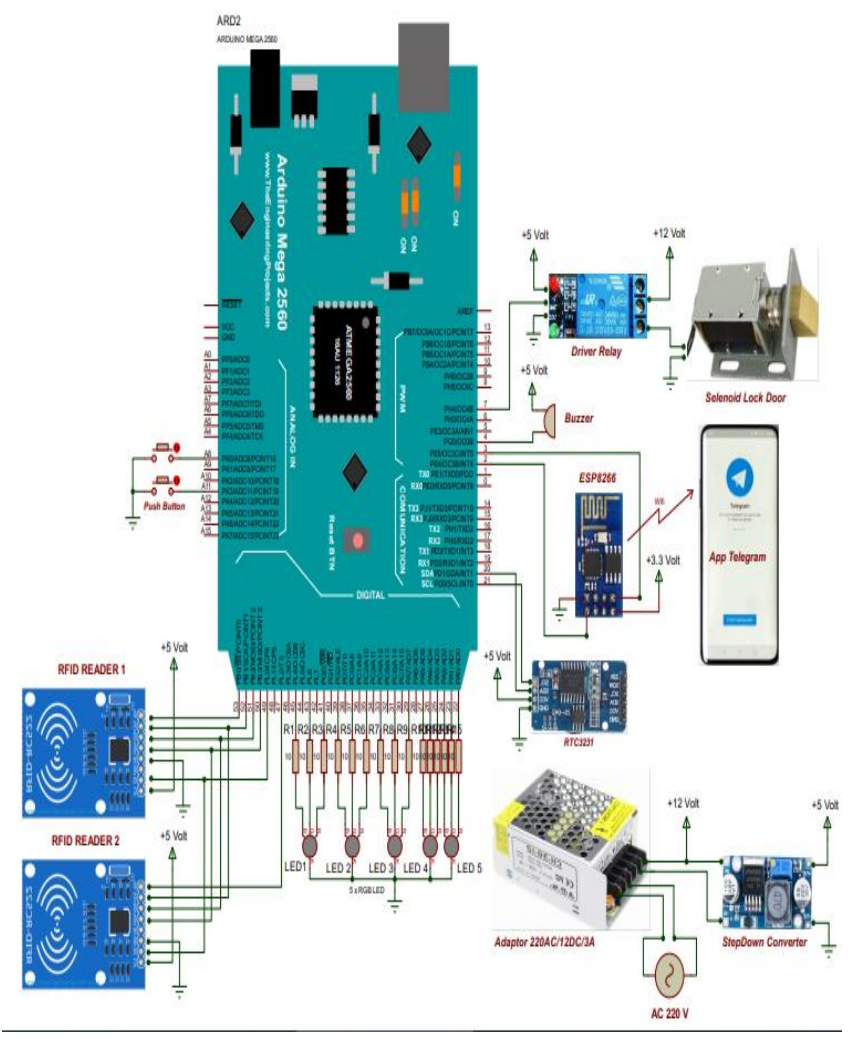

Gambar 3. Rangkaian Keseluruhan

\section{Perancangan Software}

Perancangan alat dan media informasi keberadaan dosen dalam ruangan menggunakan software arduino IDE dengan bahasa pemograman C. Untuk menjalankan alat dimulai dengan mendesain flowchart sistem dari program yang akan dibuat. 


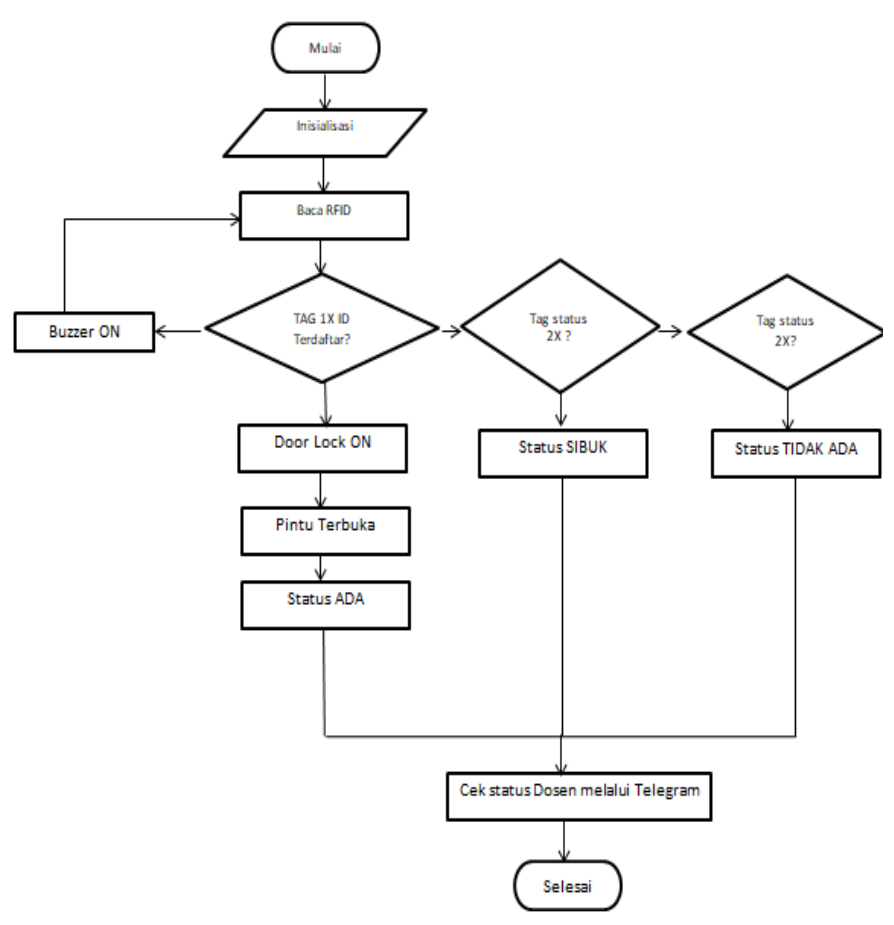

Gambar 4. Flowchart Kerja Sistem

Perancangan Flowchart merupakan perancangan logika atau urutan instruksi pemograman suatu diagram. Diagram alur dari suatu perancangan ditunjukan secara jelas dalam suatu algoritma yaitu bagaimana rencana pelaksanaan kegiatan. Perancangan Flowchart sistem dilakukan untuk mempermudah suatu perancangan software yang akan dibuat dengan melihat logika yang akan digunakan sebagai penjelasan dari urutan program yang digunakan pada perancangan alat tersebut.

\section{HASIL DAN PEMBaHASAN}

Pengujian dilakukan untuk mengetahui apakah alat berjalan dengan baik atau tidak. Untuk melakukan pengujian alat digunakan catu daya yang telah dipasang pada alat, mikrokontroler Arduino Mega 2560, RFID, Driver Relay, Selonoid Door Lock, RTC dan ESP8266, digunakan untuk menampilkan Status dari keberadaan dosen dalam ruangan berdasarkan tag yang dilakukan oleh dosen tersebut. Berikut adalah rancangan alat yang sudah dibuat dengan mengunakan akrilik sebagai kerangka rancangan.

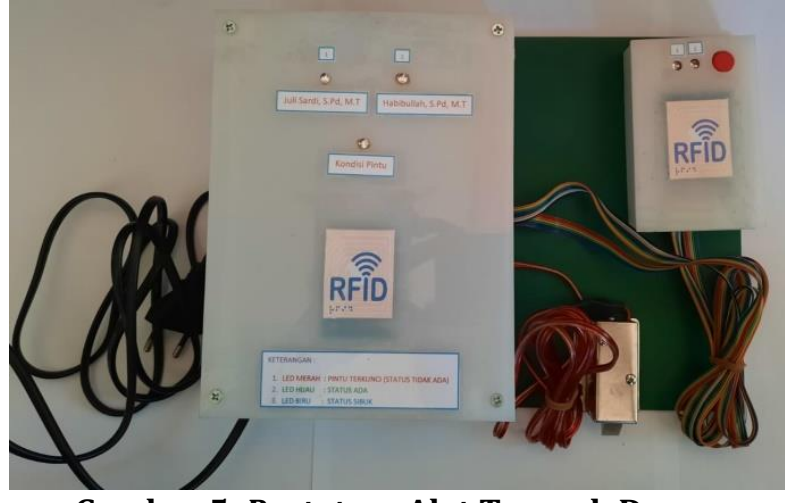

Gambar 5. Prototype Alat Tampak Depan

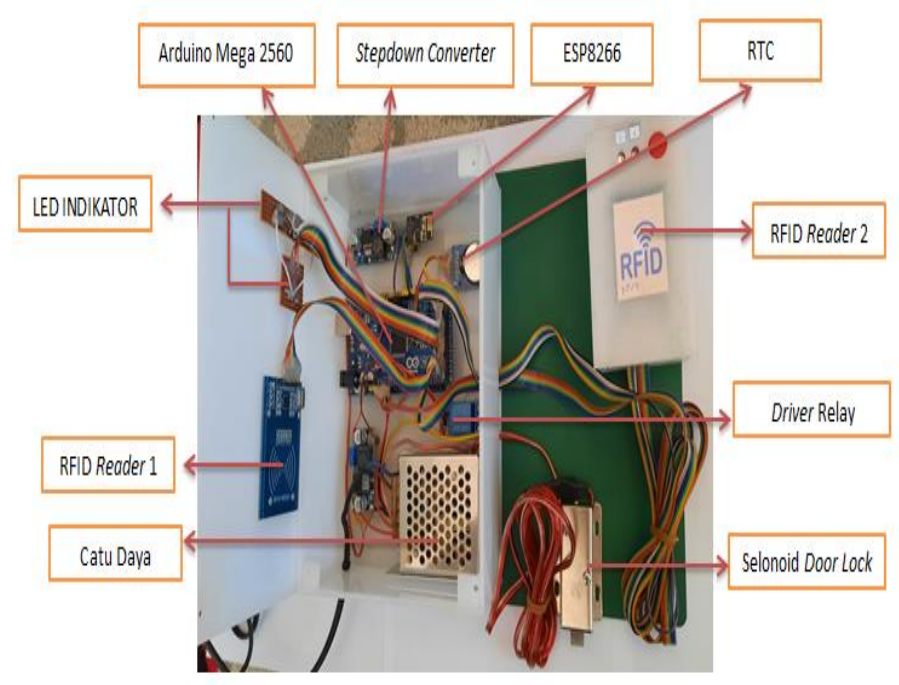

Gambar 6. Kompenen Alat Keseluruhan

Langkah Pertama yang harus dilakukan untuk mengaktifkan rancangan ini yaitu hubungkan alat pada sumber 220 Volt. Kemudian hidupkan alat untuk pertama kali pemakaian dengan memencet saklar on/off alat. Jika alat suda di aktifkan untuk mematikan dan menghidupkan kembali tidak perlu memencet tombol on/off lagi, karena alat menggunakan RTC yang dapat mengaktifkan dan menon-aktifkan alat sesuai dengan waktu yang suda di program. Setelah alat hidup maka lakukan pegujian alat dengan melakukan tag pada RFID Reader yang terdapat bagian luar pintu untuk membuka pintu dan secara otomatis status keberadaan dosen akan berubah yang dapat dilihat pada aplikasi telegram.

\section{Pengujian RFID}

Pengujian dilakukan dengan mendekatkan Kartu RFID ke RFID Reader. Apabila Kartu RFID Terdeteksi oleh RFID Reader maka Selonoid Aktif dan Pintu akan Terbuka. Apabila Kartu RFID tidak sesuai maka Selonoid Tidak Aktif dan Pintu tidak akan Terbuka. Pengujian RFID terdiri dari dua Pengujian yaitu Pengujian ID Kartu dan Pengujian Status Keberadaan Dosen Dalam Ruangan. 


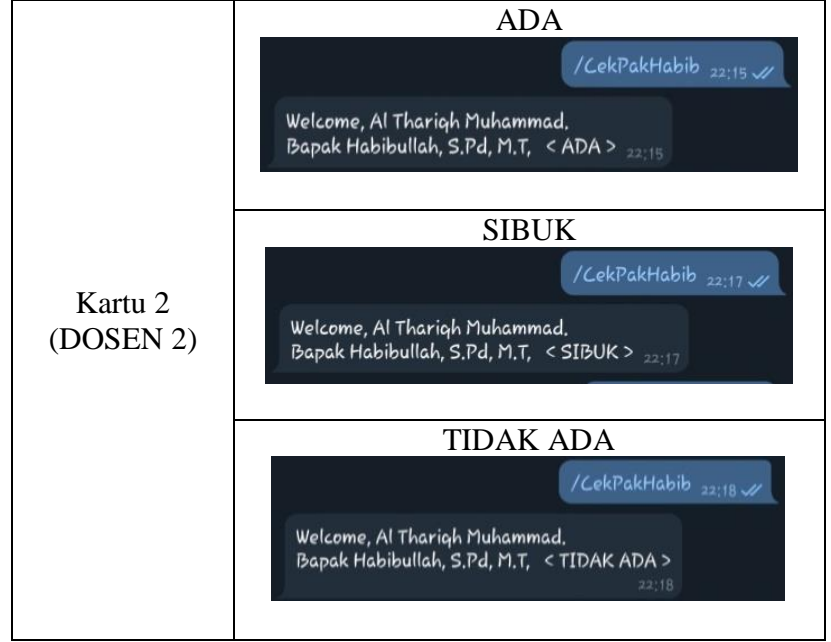

Berdasarkan tabel 3 pengujian status dosen menggunakan aplikasi terdapat tiga buah kondisi yaitu Ada, Sibuk dan Tidak Ada. Kondisi ini akan ditampilkan pada aplikasi telegram jika kondisi Ada, berarti dosen yang bersangkutan berada dalam ruangan. Jika kondisi Sibuk menandakan dosen men-tag kartu ID dari dalam ruangan berarti dosen sedang tidak ingin diganggu. Kondisi Tidak Ada menandakan dosen tidak men-tag kartu ID dan tidak sedang berada dalam ruangan.

\section{Pengujian Selonoid Door Lock}

Pengujian ini dilakukan dengan tujuan untuk menguji Selonoid Door Lock dapat berfungsi sebagai Pengunci Pintu secara Elektronik pada Ruangan tertentu. Cara pengujian Selonoid Door Lock yang dilakukan yaitu Selonoid akan membuka pintu jika perangkat RFID dalam keadaan ready. Jika Kartu ID yang digunakan Terdaftar, maka Selonoid Door Lock berada dalam kondisi Tertutup (Pintu Terbuka). Jika Kartu ID yang digunakan tidak terdaftar maka selonoid berada dalam kondisi Terbuka (Pintu Tertutup).

\section{Tabel. 4 Pengujian Selomoid Door Lock}

\begin{tabular}{|c|c|c|c|}
\hline ID RFID & $\begin{array}{c}\text { Selonoid } \\
\text { Door } \\
\text { lock }\end{array}$ & $\begin{array}{c}\text { Kondisi Selonoid } \\
\text { Door Lock }\end{array}$ & $\begin{array}{c}\text { Keteranga } \\
\mathbf{n}\end{array}$ \\
\hline Terdaftar & On & $\begin{array}{c}\text { Keadaan } \\
\text { Pintu } \\
\text { Terbuka }\end{array}$ \\
\hline Tidak & Off & $\ldots$ & $\begin{array}{c}\text { Keadaan } \\
\text { Pintu } \\
\text { Tertutup }\end{array}$ \\
\hline
\end{tabular}

\section{Pengujian ESP8266 Terhadap Aplikasi Telegram}

Pengujian ini dilakukan dengan tujuan untuk menguji Rangkaian ESP8266 dapat berfungsi sebagai indikator Penghubung rancangan (alat) dengan jaringan internet (Wifi) sebagai media untuk memberitahu keberadaan dosen dalam ruangan dengan menggunakan aplikasi yang dinamakan Telegram. Cara pengujian ESP8266 yang dilakukan yaitu ESP8266 akan memberikan informasi keberadaan dosen dalam ruangan melalui aplikasi Telegram tersebut.

Tabel 5. Pengujian ESP8266 Terhadap Aplikasi Telegram

\begin{tabular}{|c|c|l|}
\hline $\begin{array}{c}\text { Kondisi } \\
\text { ESP8266 }\end{array}$ & Telegram & \multicolumn{1}{|c|}{ Keterangan } \\
\hline ON & ON & $\begin{array}{l}\text { Informasi dapat diakses melalui } \\
\text { Telegram dengan mengetikkan } \\
\text { kode yang ditentukan. }\end{array}$ \\
\hline OFF & OFF & $\begin{array}{l}\text { Informasi tidak dapat diakses } \\
\text { melalui Telegram dengan } \\
\text { mengetikkan kode yang } \\
\text { ditentukan. }\end{array}$ \\
\hline ON & OFF & $\begin{array}{l}\text { Informasi tidak dapat diakses } \\
\text { melalui Telegram dengan } \\
\text { mengetikkan kode yang } \\
\text { ditentukan. }\end{array}$ \\
\hline OFF & ON & $\begin{array}{l}\text { Informasi tidak dapat diakses } \\
\text { melalui Telegram dengan } \\
\text { mengetikkan kode } \\
\text { ditentukan. yang }\end{array}$ \\
\hline
\end{tabular}

\section{Pengujian Rangkaian RTC}

Pengujian ini dilakukan dengan tujuan untuk menguji Rangkaian RTC dapat berfungsi sebagai indikator waktu yang digunakan sebagai pengganti status dosen secara otomatis sekaligus sebagai saklar otomatis yang dapat mematikan dan menghidupkan alat beradasarkan jam masuk dan jam pulang kerja dosen yang dimasukan dalam program perancangan.

\section{Tabel 6. Pengujian Rangkaian RTC}

\begin{tabular}{|c|c|c|}
\hline $\begin{array}{c}\text { Kondisi } \\
\text { RTC }\end{array}$ & $\begin{array}{c}\text { Jam } \\
\text { Kerja }\end{array}$ & Keterangan \\
\hline ON & $\begin{array}{c}07.00- \\
21.00\end{array}$ & $\begin{array}{l}\text { Alat dalam keadaan Hidup } \\
\text { atau aktif sehingga dapat } \\
\text { digunakan. Status Dosen } \\
\text { berdasarkan berapa kali Tag } \\
\text { kartu ID. }\end{array}$ \\
\hline OFF & $21.00-$ & Alat dalam keadaan Mati atau \\
\hline
\end{tabular}




\begin{tabular}{|l|l|l|}
\hline 06.59 & $\begin{array}{l}\text { Tidak aktif sehingga Tidak } \\
\text { dapat digunakan. Status } \\
\text { Dosen berubah otomatis jika } \\
\text { tidak dilakukan Tag sebanyak } \\
\text { 3x menjadi TIDAK ADA. }\end{array}$ \\
\hline
\end{tabular}

\section{PENUTUP}

\section{Kesimpulan}

Dari pengujian diatas dapat disimpulkan Perancangan alat pengunci pintu dengan menggunakan RFID sebagai kunci elektrik dan sistem informasi keberadaan dosen dalam ruangan dapat dilakukan dengan baik dan sesuai dengan tujuan perancangan. Sistem informasi yang diberikan dapat diakses atau diketahui melalui aplikasi Telegram dapat berfungsi dengan baik dan dapat digunakan dengan jarak jauh melalui jaringan internet dengan menggunakan intruksi atau kode yang diberikan sesuai tujuan dosen yang diingin diketahui keberadaannya.

\section{Saran}

Disarankan Penggunaan alat pengunci pintu ini dapat dilengkapi dengan sistem keamanan yang dapat bekerja secara lebih kompleks sebagai pengunci dan sekaligus sebagai pengaman ruangan. Sistem informasi keberadaan dosen dapat dikembangkan dengan menambahkan kondisi dari pengguna/dosen dan dengan metode aplikasi lainnya. Serta dapat menggunakaan sensor pengunci yang lebih tahan terhadap panas ketika penggunaan rancangan selama 24 jam.

\section{REFERENSI}

[1] Rerungan, Juprianto., Wiria, Deni Nugraha., Anshori, Yusuf."Sistem Pengaman Pintu Otomatis Menggunakan Radio Frequency Identification (RFID) Tag Card Dan Personal Identification Number ( PIN ) Berbasis Mikrokontroler AVR Atmega 128”. 2014.

[2] A. kadi. "Panduan Praktis Mempelajari Aplikasi Mikrokontroler dan Pemrogramannya Menggunakan Arduino". Edisi 1. Andi Offset. Yogyakarta. 2012.
[3] Siswanto, E., \& Nasrudin, N. "Perancangan Sistem Keamanan Ruangan Menggunakan Rfid Pada E-KTP Di Balai Desa Sukorejo". Jurnal Ilmiah Ekonomi Dan Bisnis, 11(2), 45-55. 2018.

[4] Novianti, T." Rancang Bangun Pintu Otomatis dengan Menggunakan RFID". Jurnal Teknik Elektro dan Komputer TRIAC, 6(1). 2019.

[5] Astono, R. "Implementasi Dan Pemasangan Kunci Pintu Hotel Dengan Radio Frequency Identification (RFID)". Skripsi. Program Studi Pendidikan teknik Elektro Universitas Negeri Semarang. Semarang. 2006.

[6] Dang, H. T." Investigate And Design A 13.56MHz RFID Reader". Tesis. School Of Electrical Engineering Ho Chi Minh City International University (Vietnam National University ). Ho Chi Minh. 2013.

[7] Ogata. "Perancangan Dan Penerapan Sistem Kontrol Peralatan Elektronik Jarak Jauh Berbasis Web". Jurnal Mekanikal, 6(2). 1997.

[8] Novianti, T. "Rancang Bangun Pintu Otomatis dengan Menggunakan RFID. Jurnal Teknik Elektro dan Komputer TRIAC", 6(1). 2019.

[9] Siti, Dewi Rosyana. "Rancang Bangun Pintu Otomatis Ruang Sidang Teknik Elektro UNP Dengan RFID Dan PIN Password Berbasis Arduino ATMega 2560". Tugas Akhir D-III. Universitas Negeri Padang. 2019.

[10] Triyanto, F. U. D., \& Brianorman, Y. "Prototype Sistem Keamanan Pintu Menggunakan Radio Equency Identification (RFID) Dengan Kata Sandi Berbasis Mikrokontroler". Coding Jurnal Komputer Dan Aplikasi, 3(1). 2016.

\section{Biodata Penulis}

Al Thariqh Muhammad Quithary, lahir di Padang, 03 Desember 1998. Sarjana Sains Terapan, di jurusan Teknik Elektro Program Studi DIV Teknik Elektro Indusri, Fakultas Teknik, Universitas Negeri Padang.

Hastuti, S.T, M.T. lahir di Tembilahan, 25 Mei 1976. Menyelesaikan Studi S1 Sarjana Teknik Elektro di Jurusan Teknik Elektro Universitas Andalas. Memperoleh gelar Master Teknik di Sekolah Teknik Elektro dan Informatika (STEI) ITB Bidang Sistem Kendali. Staf Pengajar di Jurusan Teknik Elektro FT-UNP Sejak tahun 2008 s.d sekarang. 